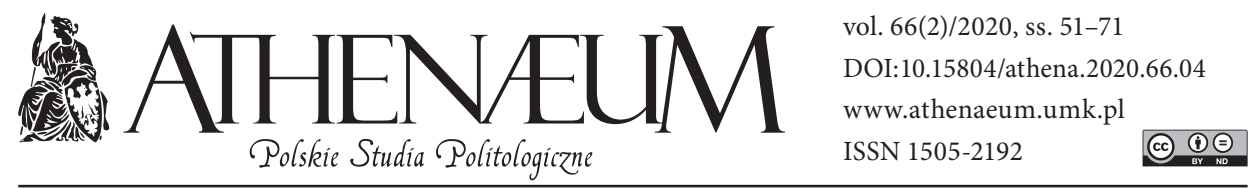

\title{
RELACJE KAZACHSKO-ROSYJSKIE I ICH ZNACZENIE DLA BEZPIECZEŃSTWA NA OBSZARZE POSTRADZIECKIM
}

\author{
KAZAKH-RUSSIAN RELATIONS AND THEIR IMPORTANCE FOR \\ SECURITY IN THE POST-SOVIET AREA
}

Paweł Bielicki* (10

\begin{abstract}
- ABSTRAKT
Przedmiotem mojego zainteresowania jest przedstawienie najważniejszych uwarunkowań polityczno-ekonomicznych relacji pomiędzy Federacją Rosyjską a Kazachstanem. Głównym celem niniejszej pracy jest opisanie obecnego stanu rzeczy we wzajemnych kontaktach i ich znaczenie dla bezpieczeństwa na terenie byłego ZSRR. Ponadto istotna będzie próba odpowiedzi na pytanie, czy w najbliższym czasie Rosja będzie odgrywała dalej istotną rolę jako partner gospodarczy i polityczny Kazachstanu po ustąpieniu w marcu 2019 r. prezydenta Nursułtana Nazarbajewa.

Na wstępie zamierzam odnieść się do historii relacji obu krajów, datowanej na czasy istnienia Związku Socjalistycznych Republik Radzieckich i kontroli Kazachskiej Socjalistycznej Republiki Radzieckiej przez władze komunistyczne na Kremlu. W dalszej części rozważań przedstawiam stosunki obu podmiotów bezpośrednio po upadku sowieckiego imperium i dojściu do wła-
\end{abstract}

The subject of my interest is to present the most important political and economic conditions of relations between the Russian Federation and Kazakhstan. The main purpose of this work is to describe the current state of affairs in mutual contacts and their importance for security in the former USSR. In addition, it will be important to try to answer the question of whether in the near future Russia will continue to play an important role as Kazakhstan's economic and political partner after the resignation of President Nursultan Nazarbayev in March 2019.

At the outset, I intend to refer to the history of the relations of both countries, dated to the times of the Union of Soviet Socialist Republics and the control of the Kazakh Soviet Socialist Republic by the communist authorities in the Kremlin. Further on, I present the relations of both entities immediately after the fall of the Soviet empire and the coming to power of Nazarbayev, who, despite his desire to conduct independent foreign policy,

* Instytut Solidarności i Męstwa im. Witolda Pileckiego w Warszawie. 
dzy Nazarbajewa, który mimo chęci prowadzenia niezależnej polityki zagranicznej, utrzymywał ścisłe polityczne i gospodarcze więzi z Rosją, a także więzi wojskowe. Następnie poruszam problem kontaktów Moskwa-Nursułtan po aneksji Krymu, oraz więzi Kazachstanu ze Stanami Zjednoczonymi oraz Chinami. Chciałbym też odnieść się do implikacji wyboru na prezydenta Kasyma Tokajewa dla relacji z Rosją, Chinami oraz światem zachodnim. Dodatkowo prześledzę zależności ekonomiczne i kulturalne, występujące pomiędzy Rosją a Kazachstanem.

W podsumowaniu uwypuklam perspektywy na przyszłość i staram się odpowiedzieć na pytanie, czy obecne relacje obu krajów ulegną intensyfikacji w obliczu objęcia urzędu prezydenta przez Tokajewa, a także w jaki sposób wpływają one na bezpieczeństwo na obszarze postradzieckim.

Słowa kluczowe: Rosja; Kazachstan; bezpieczeństwo; obszar postradziecki; Nazarbajew maintained close political and military ties with Russia. Then I raise the issue of contacts between Moscow and Nursultan Nazarbayev after the annexation of Crimea and Kazakhstan's ties with the United States and China. I would also like to refer to the implications of electing President Kassym Tokayev for relations with Russia, China and the Western world. In addition, I will trace economic and cultural dependencies between Russia and Kazakhstan.

In the summary, I highlight future perspectives and try to determine whether current relations between the two countries will intensify in the face of Tokayev taking office as president, and how they affect security in the post-Soviet area.

Keywords: Russia; Kazakhstan; security; post-Soviet area; Nazarbayev

\section{WPROWADZENIE}

Stosunkowo niedawne wydarzenia, mające miejsce na obszarze postradzieckim, związane z agresywną polityką Federacji Rosyjskiej m.in. na Ukrainie i jednoczesne zbliżenie rosyjsko-chińskie oraz opuszczenie rodzimej sceny politycznej przez wieloletniego prezydenta Kazachstanu, Nursułtana Nazarbajewa - obligują do postawienia pytań o aktualny obraz stosunków międzypaństwowych w azjatyckiej przestrzeni postsowieckiej. Jednym z jej elementów są relacje rosyjsko-kazachskie. Niniejsze opracowanie poruszy relacje obu tych podmiotów, skupiając się szczególnie na okresie od trzeciej kadencji Władimira Putina jako prezydenta Federacji Rosyjskiej, do chwili obecnej. W szczególnej mierze chciałbym dotknąć problematyki stosunków między stronami po rosyjskiej aneksji Krymu oraz ustąpieniu Nazarbajewa z funkcji prezydenta Kazachstanu, który przez 27 lat sprawowania tego urzędu potrafił dbać o poprawne kontakty z Moskwą. Istotne także wydaje się przedstawienie przybierającego na sile wpływu Chin na politykę byłej sowieckiej republiki i znaczenia wzajemnych relacji dla rozwoju bądź zaniku więzi Moskwy z Nursułtanem. Właściwe będzie też wspomnienie o relacjach Rosji i Kazachstanu na płaszczyźnie ekonomicznej, 
szczególnie w aspekcie wspólnej działalności obu krajów w Szanghajskiej Organizacji Współpracy (SOW) oraz Eurazjatyckiej Wspólnocie Gospodarczej (EaWG). Dodatkowo zasadne będzie przywołanie więzów kulturowych łączących oba kraje i ich dotychczasową współpracę militarną. Podstawowe pytania badawcze dotyczą kwestii określenia uwarunkowań wzajemnych kontaktów bezpośrednio po upadku ZSRR, wpływu aneksji Krymu na te więzi na płaszczyźnie ekonomicznej, kulturalnej i wojskowej, woli wprowadzenia istotnych zmian w przedmiotowej materii przez nowego kazachskiego prezydenta Tokajewa i określenia obecnego poziomu zintensyfikowania kontaktów obu krajów czy odniesienia się do aktualnych relacji Kazachstanu z Chinami i Stanami Zjednoczonymi Ameryki Północnej.

\section{GENEZA RELACJI KAZACHSKO-ROSYJSKICH}

Współczesne relacje rosyjsko-kazachskie należy determinować rozpadem Związku Sowieckiego, w skład którego wchodziła socjalistyczna republika Kazachstanu. Wcześniej, od 1920 r. do 1925 r., istniała ona jako Kirgiska Autonomiczna Socjalistyczna Republika Radziecka. Znaczące przyspieszenie przemian na wzór sowiecki rozpoczęło się w 1925 r. po dojściu do władzy w republice Filipa Goloshchykina, którego celem była zmiana stylu życia Kazachów z koczowniczego na bardziej przystający do sowieckich realiów (Kazachstan upamiętnia stalinowski terror). Bolszewicy mieli początkowo jednak pewne problemy z utrwaleniem sowieckiej wersji komunizmu ze względu na występowanie wcześniej w Kazachstanie podziałów żuzowych. Żuzy, będące zrzeszeniem polityczno-społecznym, skupiającym różne plemiona zamieszkałe w kraju, stanowiły pewną przeszkodę w umacnianiu władzy radzieckiej, ponieważ za ich sprawą rosło znaczenie tożsamości lokalnej. Największy ich wpływ był obecny na północy, południu i zachodzie kraju. Pomimo tego zasięg ich oddziaływania uległ znacznej deprecjacji za czasów przynależności Kazachstanu do Związku Radzieckiego, gdyż zostały one wyparte przez różne grupy interesów, szczególnie przedstawicieli nomenklatury składającej się z działaczy KPZR (Jarosiewicz, 2016, s. 19). Ponadto istotną rolę w stłumieniu wszelkiej opozycji odegrała kolektywizacja rolnictwa przeprowadzona na początku lat 30. XX wieku. Niektóre źródła szacują, że przymusowe przesiedlanie Nomadów spowodowało głód, zabijając 1,75 miliona Kazachów (czterdzieści procent całej ludności) i zmusiło dalsze setki tysięcy do ucieczki do sąsiednich republik lub poza granice kraju 
(Oka, 2007, s. 37). Status „samodzielnej” republiki sowieckiej Kazachska SRR uzyskała w 1936 r., a na jej czele stanął Lewon Mirzojan, skazany na śmierć w czasach Wielkiego Terroru (Kassymova, Kundakbaeva, Markus, 2012, s. 303). W późniejszych latach do Kazachskiej Socjalistycznej Republiki Radzieckiej (KSSR) zostały przeniesione zakłady przemysłowe z europejskiej części ZSRR, co spowodowało, że w okresie powojennym Kazachstan stał się jedną z najbardziej gospodarczo rozwiniętych republik radzieckich. Przyczyniła się do tego także ogólnokrajowa kampania zagospodarowania nieużytków rolnych prowadzona od 1954 r. do 1960 r. przez następcę Stalina, Nikitę Chruszczowa. Można jednak wysnuć przypuszczenie, że stosunkowo dobra sytuacja ekonomiczna republiki spowodowała, że była ona postrzegana przez Moskwę jako zagrożenie dla spoistości imperium. Z tego też względu kazachscy działacze partyjni po śmierci Stalina nie zrobili znaczącej kariery politycznej. Nie jest tajemnicą, że do radzieckiego kierownictwa partyjnego w Moskwie kierowani byli ludzie ormiańskiego pochodzenia (Anastas Mikojan), gruzińskiego (Ławrientij Beria) czy żydowskiego (Łazar Kaganowicz, Karol Radek), a później ukraińskiego - jak m.in. późniejszy przewodniczący Rady Najwyższej ZSRR Nikołaj Podgórny czy szef partii ukraińskiej Wołodymyr Szczerbicki, typowany przez niektórych na następcę Leonida Breżniewa na fotelu sekretarza generalnego KPZR (Ducret, Hecht, 2014, s. 165-166). Rzuca się natomiast w oczy brak w kierownictwie partii ludzi z Kazachstanu (Shibutov, Solozobov, Malyarchuk, 2019, s. 21). Podobna sytuacja dotyczyła innych polityków z Azji Centralnej, którzy prawdopodobnie ze względu na ograniczone etnicznie i kulturowo więzi z Rosją nie zyskiwali aprobaty wśród władz centralnych. Dlatego też przez długi czas istotną rolę w państwie sowieckim odgrywali działacze, przysyłani bezpośrednio z Moskwy, tacy jak wspominany wyżej Breżniew, sprawujący w latach 1954-1955 urząd II sekretarza KC partii kazachskiej. Dla przyszłego sekretarza generalnego KPZR epizod kazachski odegrał ważną rolę we wspięciu się na szczyt sowieckiej hierarchii partyjnej. Pomimo wysiłków Moskwie nigdy nie udało się jednak przejąć całkowitej kontroli nad KSSR, gdyż w dalszym ciągu to rodowici Kazachowie odgrywali istotną rolę w obsadzie stanowisk wewnątrz struktur władzy republiki. Przez długie lata na czele kazachskiej partii komunistycznej stał Dynmuchamed Kunajew, który starał się zaprowadzić równowagę między rodowitymi Kazachami a Rosjanami. Za jego rządów rozwinęła się w republice kazachskiej nomenklatura, w której niejednokrotnie znaczącą rolę odgrywały powiązania działaczy politycznych z Kremlem, ale także więzi rodzinne. Jak pisał I. Ziemcow, za rządów Kunajewa w celu pracy w wyższych organach partyjnych 
w Kazachstanie niezbędna była siła przebicia i elastyczność, a żeby utrzymać zdobytą władzę, potrzebny był brak zasad i służalczość (Załęski, 2006, s. 131).

Zmianę sytuacji przyniosło ogłoszenie przez nowego szefa radzieckiej partii komunistycznej Michaiła Gorbaczowa programu pierestrojki i stopniowej liberalizacji systemu politycznego ZSRR. Jego reformy ujawniły istniejące wcześniej podskórnie antagonizmy narodowościowe pomiędzy Rosjanami a Kazachami, zamieszkującymi głównie południe kraju. Pierwszym przejawem narastających problemów stały się protesty młodych ludzi przeciwko mianowaniu w grudniu 1986 r. na stanowisku I sekretarza KC KP Kazachstanu Giennadija Kołbina, będącego z pochodzenia Rosjaninem (Pichoja, 2011, s. 520-521). Dla Kremla jasnym było, że pomimo użycia wojska przez władze lokalne przeciwko protestującym należy poczynić działania w celu uporządkowania relacji narodowościowych. Dalsze przyspieszenie przemian nastąpiło na przełomie lat 80 . i 90. po objęciu przez Nursułtana Nazarbajewa w 1989 r. funkcji szefa kazachskiej partii komunistycznej. Nazarbajew, będący zwolennikiem Gorbaczowa, dostrzegł, że sowieckie imperium zaczyna się rozpadać, lecz zachował postawę wyczekującą ostatecznych rozstrzygnięć w Moskwie. Dopiero po nieudanym puczu z sierpnia 1991 r. podjął on decyzję o wystąpieniu z KPZR (Pichoja, 2011, s. 670-671). Kilka miesięcy później, 1 grudnia, został pierwszym prezydentem niepodległego państwa (zob. Prezydent Kazachstanu oddaje tytut, ale nie władzę, 2019).

\section{STOSUNKI POLITYCZNO-MILITARNE KAZACHSTANU Z ROSJA. WPŁYW ANEKSJI KRYMU NA WZAJEMNE RELACJE}

Jednym z poważniejszych problemów, przed jakimi stanął nowy prezydent, stała się kwestia dalszej dyslokacji na terenie kraju broni atomowej. Kazachstan, który wcześniej był jednym z ważniejszych obszarów, na którym Moskwa wykonywała próbne wybuchy atomowe, m.in. we Władymirowce, Embie i Semipałatyńsku do 1991 r., był także rejonem składowania broni nuklearnej. Sytuację pogarszał fakt, że Kazachstan w dniu uzyskania niepodległości posiadał prawie tyle głowic co Francja, Wielka Brytania i Chińska Republika Ludowa razem wzięte. Nazarbajew zdawał sobie sprawę, że broń atomowa może stanowić zagrożenie dla jego władzy, gdyż żadne z mocarstw - szczególnie Stany Zjednoczone i Rosja - nie wyrażą zgody na dołączenie biednego i zacofanego państwa do klubu państw dysponujących tego rodzaju bronią. W rozmowie $\mathrm{z}$ ówczesnym prezydentem USA George’m Bushem w maju 1992 r., w zamian za rezygnację z atomu zażądał 
on gwarancji bezpieczeństwa od USA (Potocki, 2016). Po długich negocjacjach kazachski prezydent podjął decyzję, że do 1995 r. odda Moskwie wszystkie głowice atomowe, co zostało zrealizowane (Rakowska, 2005).

Akcentowano wówczas, że ze względu na trudną historię - nawet przy ugodowej polityce Kazachstanu wobec Kremla - partnerskie stosunki kazachsko-rosyjskie mogą natrafić na pewne przeszkody. Już w 1999 r. rosyjski badacz Aleksandrow, opisując relacje obu podmiotów w latach 1991-1997, stwierdzał, że jest to „niełatwy sojusz” (Zaborsteva, Russia relations, 2016, s.40). Rosjanie, szczególnie w okresie rządów prezydenta Jelcyna i upadku znaczenia państwa rosyjskiego na arenie międzynarodowej, dostrzegali, że kraje postsowieckie, mimo silnych więzi z Rosją, zmierzać będą do uniezależnienia się od Moskwy i prowadzenia własnej polityki. Bezpośrednio po rozpadzie ZSRR traktowane były jako część „bliskiej zagranicy” w oparciu o „rosyjską doktrynę Monroe’a”, dobitnie podkreślającą, że należą one do bezpośredniej strefy wpływów Rosji, ze względu na to, że Kreml ma tam „żywotne” interesy na płaszczyźnie politycznej, gospodarczej i militarnej. Dowodem takiego traktowania było podpisanie w maju 1992 r. na okres 5 lat Układu o bezpieczeństwie zbiorowym, zwanego traktatem taszkienckim (Mazur, 2007, s. 172-173). Pomimo kryzysu działań Wspólnoty Niepodległych Państw (WNP) w II połowie lat 90. Kazachstan wraz z Białorusią, Armenią, Kirgistanem oraz Turkmenistanem czynnie popierał politykę Moskwy w regionie i zaliczał się do tzw. twardego jądra WNP (Mazur, 2007, s. 177). Także w kolejnych latach, po dojściu w Rosji do władzy Władimira Putina, współpraca podmiotów była kontynuowana, czego dowodzi utworzenie w 2002 r. Organizacji Układu o Bezpieczeństwie Zbiorowym w składzie: Rosja, Kazachstan, Armenia, Kirgistan, Tadżykistan i Białoruś. Dokument ten stanowił o wzmocnieniu przez Rosję jej pozycji w Azji Centralnej, szczególnie w obliczu zwiększonej aktywności Stanów Zjednoczonych na obszarze postsowieckim.

Konieczność utrzymywania przez Kazachstan poprawnych relacji z Moskwą została dodatkowo uwarunkowana innymi względami. Istotne jest przypomnienie, że ze wszystkich krajów postsowieckich Kazachstan ma najdłuższą granicę z Rosją. Dlatego pod względem bezpieczeństwa narodowego i regionalnego obie strony są bardzo współzależne i istnieje wiele obszarów podatności na zagrożenia. Ponadto z byłych republik radzieckich, które graniczą z Rosją, tylko Białoruś i Kazachstan uczestniczą w integracji euroazjatyckiej i mają wspólną przestrzeń gospodarczą z Rosją. Wreszcie populacja Kazachstanu w dużej mierze jest zespolona z obywatelami uważającymi rosyjską przestrzeń społeczno-kulturową za swoją własną, co jest pośrednio związane z wieloletnią przynależnością 
Kazachów do Związku Sowieckiego. Dodatkowym czynnikiem, sprzyjającym dwustronnej współpracy, jest fakt, że przywódcy Kazachstanu i Rosji od początku istnienia niepodległego państwa kazachskiego mieli ze sobą dobre, osobiste relacje. W przekonaniu eksperta od spraw kazachskich, Askara Nurshy, oznacza to, że władze Kazachstanu dostrzegają strategiczne znaczenie Rosji na arenie międzynarodowej. Dlatego utrzymywanie z nią relacji politycznych jest potrzebne dla rozwoju państwa (zob. Russia and Kazakhstan: What's Next, 2019). Słowa analityka są odzwierciedlone w koncepcji polityki zagranicznej Kazachstanu, dotyczącej stosunków z Rosją. Czytamy w niej, że „Republika Kazachstanu będzie nadal umacniać stosunki z Federacją Rosyjską we wszystkich dziedzinach współpracy politycznej, handlowej, gospodarczej, kulturalnej i humanitarnej na podstawie traktatu o dobrych stosunkach sąsiedzkich i sojuszu w XXI wieku" (Shibutov, Solozobov, Malyarchuk, 2019, s. 7). Innymi słowy, dla władz kazachskich współpraca z Rosją stanowi jeden z głównych instrumentów polityki zagranicznej, przyczyniających się do rozwoju kraju.

Analizując z kolei stosunek Rosji wobec Kazachstanu, należy dostrzec parę zasadniczych prawidłowości. Przede wszystkim wypada zauważyć, że polityka Moskwy wydaje się być zależna od działań władz kazachskich oraz przypadkowych zdarzeń na arenie międzynarodowej. Według Marata Shibutova, Jurija Solozobova oraz Natalii Malyarchuk, taka nieprzewidywalność polityki zagranicznej Rosji stwarza dla Kazachstanu pewne problemy, gdyż władze byłej republiki sowieckiej są zmuszone dostosować się do Rosji i czekać na ostateczną decyzję Moskwy w poszczególnych sprawach (Shibutov, Solozobov, Malyarchuk, 2019, s. 8). Właściwe będzie jednak przypuszczenie, że pomimo niewątpliwej chęci zdobycia silniejszej kontroli nad Kazachstanem Kreml stara się niwelować sporne kwestie z tym państwem, zdając sobie sprawę z jego licznych zasobów naturalnych oraz możliwych dróg dywersyfikacji kierunków ich eksportu. Moskwa doskonale zdaje sobie sprawę, że w wypadku konfliktu Kazachstan mógłby się zwrócić z prośbą o pomoc gospodarczą do m.in. Chin, Iranu, Turcji, czy nawet Stanów Zjednoczonych (Tokarz, 2008, s. 240-241). Zdaniem Grzegorza Tokarza Rosja nigdy nie stanowiła zagrożenia dla Kazachstanu, a w sytuacji możliwości destabilizacji politycznej kraju była gotowa poprzeć Nazarbajewa. Według eksperta Rosja jest zbyt słaba, żeby podporządkować sobie Kazachstan, kraj o dużym znaczeniu na arenie międzynarodowej (Tokarz, 2008, s. 241). Wydaje się jednak, że Moskwa od czasów Jelcyna unika napięć z Kazachstanem, dostrzegając fakt, że reżim Nazarbajewa zdecydowanie nieufnie podchodził do Zachodu i mimo nawiązania kontaktów gospodarczych ze Stanami Zjednoczonymi nie przejawiał 
woli politycznego zbliżenia ze światem zachodnim, widząc, nie bez racji, brak zrozumienia Zachodu wobec obszaru postsowieckiego i jego najważniejszych problemów politycznych i gospodarczych.

Niewątpliwie na stosunki rosyjsko-kazachskie znacznie wpłynęła aneksja Krymu dokonana przez Rosję w 2014 r. Przyjmując możliwość, że Kazachstan może być następnym potencjalnym celem Rosji, prezydent Nazarbajew oficjalnie w sporze rosyjsko-ukraińskim zachował neutralność, wzywając jednocześnie do nieizolowania Moskwy na arenie międzynarodowej. Kazachstan uznał co prawda referendum na Krymie z marca 2014 r. za legalne, aczkolwiek oficjalnie nie uznał Krymu jako część Federacji Rosyjskiej. Rząd w Astanie podjął także decyzję o wstrzymaniu się od głosu nad rezolucją ONZ, potępiającą przyłączenie Półwyspu Krymskiego do Rosji (Jarosiewicz, 2015, s. 26). Mimo poprawności wzajemnych stosunków obu podmiotów kontrowersje budziły wypowiedzi przedstawicieli rosyjskiej administracji, w tym samego prezydenta Putina, sugerujące, że Kazachstan nigdy nie miał własnej państwowości (zob. Putin: Kazachowie nigdy nie mieli państwowości, 2014). Nie ulega wątpliwości, że rosyjski prezydent podkreślał w ten sposób, że Kazachstan wiele dekad znajdował się pod bezpośrednią rosyjską kontrolą (od 1868 r. do 1991 r.) i z tego tytułu Moskwie niejako należy się utrzymanie w tym kraju swoich wpływów. Bardziej bezpośrednie stanowisko zajęli inni rosyjscy politycy, m.in. Władimir Żyrinowski, który zażądał włączenia północnej części Kazachstanu do Rosji (Jarosiewicz, 2014). Dlatego też władze w Nursułtanie przyspieszyły tempo reform wewnętrznych, szczególnie na płaszczyźnie ekonomicznej. Kreml unikał podjęcia zdecydowanych kroków wobec Kazachstanu także z tego względu, że otwarta konfrontacja z Nazarbajewem może wiązać się nie tylko z pogorszeniem się stosunków rosyjsko-chińskich, ale jest też zwyczajnie niepotrzebna, gdyż szef kazachskiego państwa - w odróżnieniu do władz w Kijowie - nigdy nie opowiedział się w swojej polityce wyraźnie po stronie Zachodu. Zdaniem Jakuba Korejby, będąc z własnej woli pod rosyjską kontrolą po upadku ZSRR, Kazachowie skwapliwie wykorzystali rosyjskie gwarancje bezpieczeństwa i dostępność rynku do umocnienia własnej tożsamości narodowej i ugruntowania państwowości, nawiązując jednocześnie wielopłaszczyznowe kontakty z innymi krajami europejskimi oraz azjatyckimi. Analityk przekonuje, że Kazachstan stał się już na tyle silnym państwem, że nie zważając na Rosję i Chiny, może coraz bardziej pokazywać swoją niezależność od Moskwy, nie naruszając przy tym równowagi sił w regionie (Korejba, 2012). 
Prawdopodobnym jest, że rosyjska aneksja Półwyspu Krymskiego zacieśniła także współpracę między Chinami a Kazachstanem. Oba kraje, mające podobny system polityczny, uważają, że coraz silniejsze wzajemne kontakty umożliwią im odrzucenie bądź marginalizowanie zachodniej presji, a także osłabią moskiewskie wpływy na obszarze postsowieckim w Azji. Chiny, które za rządów Xi Jinpinga od 2013 r. stopniowo odchodzą od pacyfizmu w polityce zagranicznej, uznały, że Kazachstan może stać się jednym $\mathrm{z}$ ważniejszych elementów w realizacji ich strategii ekspansji na tereny postradzieckie. Należy jednak zaznaczyć, że realizują one strategię poprawy więzi z Kazachstanem głównie przez projekty gospodarcze, m.in. Nowy Jedwabny Szlak, który ma przebiegać przez terytorium Kazachstanu. Zdaniem Carolijn van Noort rozszerzenie kooperacji kazachsko-chińskiej przy tej inicjatywie może sprzyjać powrotowi do koncepcji Państwa Środka, dotyczącej współpracy międzykontynentalnej Azja-Europa, także w aspekcie polityki energetycznej (Van Noort, 2019, s. 14-15). Należy zwrócić uwagę, że Rosja, mająca dużo innych priorytetów w polityce zagranicznej: przypadek Ukrainy, konflikt w Syrii czy problemy europejskie - ze spokojem odbiera rosnące wpływy Pekinu w Kazachstanie, zdając sobie sprawę, że ekspansja Chin jest dużo mniejszym złem niż ekspansja Zachodu. Władze na Kremlu słusznie uważają, że oficjalnie głoszony sojusz chińsko-rosyjski służy wykazaniu na arenie wewnętrznej i zewnętrznej, że Rosja jest szanowanym na świecie państwem, liczącym się w różnych konfiguracjach międzynarodowych, w których Pekin bierze czynny udział. Z tego też względu Rosjanie nie są w stanie zaryzykować oficjalnej krytyki chińskich poczynań wobec ich rosnących wpływów w Kazachstanie. Można domniemywać stwierdzenie, że wobec przyzwolenia na takie działania w Nursułtanie Rosja nie przejawia równocześnie większej niż do tej pory chęci aktywności gospodarczej w Kazachstanie, m.in. w sferze dostaw dla tego kraju gazu i ropy, nawet w obliczu detronizacji Kremla w tym zakresie w okresie kilkunastu najbliższych lat (Hubner, 2014, s. 25). Ponadto nie bez racji należy stwierdzić, że w odróżnieniu od Zachodu Chiny są podmiotem, który nigdy nie krytykował kazachskiego systemu politycznego, oczekując jedynie realizowania określonych wynegocjowanych kontraktów ekonomicznych. Zbliżenie kazachsko-chińskie jest tym istotniejsze, że Kazachowie przez wiele lat bardzo nieufnie podchodzili do ambicji Państwa Środka na obszarze postsowieckim, uważając, że dąży ono do zastąpienia ZSRR jako państwa kontrolującego. Nie ulega wątpliwości, że dla Pekinu Kazachstan jest krajem, w którym na wypadek potencjalnego konfliktu z Moskwą trzeba byłoby poczynić w nim zwiększone inwestycje energetyczne, przyczyniające się do pogłębienia dywersyfikacji swoich źródeł energii (Kośka, 2014). 
Dla relacji rosyjsko-kazachskich ważne jest także prześledzenie związków amerykańsko-kazachskich. Chociaż terytoria postradzieckie stanowią jeden z mniej istotnych terenów dla waszyngtońskiej dyplomacji, to Amerykanie od powstania niepodległego Kazachstanu prowadzą z tym państwem interesy ekonomiczne i wojskowe. Dowodem tego były prowadzone w 2017 r. trzymiesięczne wspólne „ćwiczenia” wojskowe Stepowy Orzeł 2017. Co ciekawe, władze kazachskie wyraziły chęć kontynuacji takiej kooperacji (Budzisz, 2019). Wszystkie podobne kroki wywołały zaniepokojenie w Moskwie. Należy jednak zwrócić uwagę, że ze względu na bliskie relacje z Chinami i Rosją właśnie, władze w Astanie wystrzegały się zbyt daleko idącego zbliżenia politycznego z USA. Nazarbajew prowadził dużo bardziej stabilną politykę niż inne kraje z obszaru postradzieckiego. Potwierdza to Aleksander Baumow, czołowy rosyjski analityk. W jego przekonaniu Kazachstan od lat konsekwentnie buduje dobre relacje z USA, nie rezygnując z uczestnictwa w zdominowanych przez Rosję strukturach obronnych, prowadząc dużo bardziej stabilną politykę niż np. prezydent Łukaszenka. Według Baumowa Nazarbajew wykorzystywał znaczenie geostrategiczne swojego kraju w celu pośredniczenia między USA, Rosją a Chinami (Kacewicz, 2018). Powinniśmy jednak zauważyć, że wieloletni przywódca kraju przeliczył swoją rolę w mediacji między skłóconymi mocarstwami. Nie zweryfikował on w wystarczającym stopniu panującego wśród zachodnich elit politycznych przekonania, że Kazachstan jest krajem zacofanym gospodarczo, leżącym w dawnej przestrzeni postsowieckiej, będącym pod wpływem Rosji i nieprzestrzegającym reguł demokratycznych. Potwierdzała to chociażby wypowiedź byłego premiera Wielkiej Brytanii Davida Camerona, który w 2013 r. skrytykował nieprzestrzeganie praw człowieka w Kazachstanie (zob. Nazarbajew krytykuje Camerona, 2013).

Niespodziewana rezygnacja Nazarbajewa $\mathrm{z}$ funkcji prezydenta kraju w marcu 2019 r. i wybór Kasyma-Żomarta Tokajewa na jego następcę nie doprowadzi do znaczących zmian w relacjach rosyjsko-kazachskich. Nowy szef państwa, w przeszłości sowiecki dyplomata w Singapurze oraz Pekinie, z dużą dozą prawdopodobieństwa będzie kontynuował dotychczasową politykę swojego poprzednika, polegającą na działaniach równoważących swojego kraju między ZSRR a Chinami przy unikaniu znaczącego zbliżenia z Zachodem. Tokajew potwierdził kontynuację wcześniejszej polityki w odniesieniu do Rosji w czasie spotkania z Putinem w kwietniu 2019 r. Warto dodać, że Moskwa była pierwszą stolicą odwiedzoną przez nową głowę państwa kazachskiego (zob. Rosja: Tokajew do Putina, 2019). Prezydent Kazachstanu wyraził pogląd, że Rosja jest absolutnie kluczowa dla kierowanego przez niego kraju, gdyż jest to „duży, sąsiedni kraj, 
stały członek Rady Bezpieczeństwa ONZ”. Dodał także, że obie strony prowadzą „bardzo dobre i merytoryczne” rozmowy, a prezydent Putin nie przedstawia żadnych żądań wobec Kazachstanu, wyrażając zrozumienie dla zacieśnienia wzajemnej współpracy” (zob. Relations with Russia crucial for Kazachstan, 2019). Wydaje się, że procesowi zbliżania się Tokajewa do Chin, ale przede wszystkim do Moskwy, będzie towarzyszyło dalsze łamanie praw człowieka w Kazachstanie i tłumienie manifestacji przeciwko sukcesji, do czego dochodziło w czasie ostatnich wyborów prezydenckich, gdy Tokajew zdobył prawie 70\% głosów, oraz po ich zakończeniu (Marszewski, 2019). Chociaż nowo wybrany prezydent zadeklarował działania na rzecz społeczeństwa obywatelskiego, a także stworzył Krajową Radę Zaufania Publicznego, mającą sprzyjać w kraju procesom demokratycznym (Kazachstan: prezydent deklaruje działania, 2019), to mało prawdopodobne jest, że będzie on chciał znacząco zmienić ustrój państwa. Siłą rzeczy autorytarna polityka będzie go wpychała w ramiona Kremla, wyrażającego podobny stosunek do koncepcji demokratycznych.

Z kolei aspekt wojskowy współpracy rosyjsko-kazachskiej istnieje nieprzerwanie od rozpadu Związku Radzieckiego. Potwierdzeniem jej była inicjatywa Nazarbajewa z 21 grudnia 1991 r., dotycząca stworzenia sił pokojowych WNP na obszarze postsowieckim. Siły te w założeniu miały wygaszać wszelkie konflikty zbrojne na przedmiotowych terytoriach, nadzorować porozumienia wojskowe oraz wysyłać obserwatorów wojskowych w sporne regiony (Legucka, 2013, s. 239). W kolejnych latach kontakty na płaszczyźnie wojskowej były kontynuowane i rozwijane. Dowodem, pozwalającym na wysunięcie niniejszego stwierdzenia, jest m.in. uczestnictwo obu podmiotów w Organizacji Traktatu o Bezpieczeństwie Kolektywnym. Ponadto państwo kazachskie partycypuje w Połączonym Systemie Obrony Lotniczej WNP czy we Wspólnych Siłach Szybkiego Reagowania w Regionie Środkowo- Azjatyckim. Co jest niezwykle istotne, oba państwa podpisały także w 2003 r. Ugodę o wspólnym użyciu wojsk w celu zabezpieczenia wspólnego bezpieczeństwa (Baluk, 2008, s. 261-262). Kooperacja jest prowadzona także na płaszczyźnie edukacji wojskowej, kupna broni i amunicji, a także w wymiarze technicznym, tworzenia zbiorowych jednostek wojskowych poszczególnych rodzajów sił zbrojnych oraz kooperacji wojskowych ekspertów (Shibutov, Solozobov, Malyarchuk, 2019, s. 40). Warto zaznaczyć, że Rosja zapewnia dostawy broni rosyjskiej do Kazachstanu, a także pomoc w utrzymaniu i modernizacji sprzętu wojskowego. Rosja także dzierżawi cztery poligony wojskowe zlokalizowane w Kazachstanie. Współpracę dopełnia szkolenie kazachskiego personelu wojskowego w rosyjskich szkołach 
wojskowych (zob. Russia-Kazakhstan). Istotne jest ponadto utworzenie w $2013 \mathrm{r}$. Zunifikowanego Systemu Obrony Powietrznej Republiki Kazachstanu i Federacji Rosyjskiej jako integralnej części jednolitego systemu sił powietrznych państw członkowskich Wspólnoty Niepodległych Państw, którego cel stanowi rozpoznanie radiolokacyjne i radiowe, terminowe rozpoczęcie przygotowań obronnych w wypadku zewnętrznej agresji, ochrona i bezpieczeństwo przestrzeni powietrznej na granicach państwowych Rosji i Kazachstanu, monitorowanie zgodności z wykorzystaniem przestrzeni powietrznej, wymuszanie lądowania samolotów, które naruszają przestrzeń powietrzną Rosji lub Kazachstanu, powiadamianie oddziałów sił zbrojnych stron o przelotach statków rozpoznawczych i przekazywanie informacji o sytuacji powietrznej w sieciach alarmowych, a także informowanie kontrolerów ruchu lotniczego o zbiorczych danych dotyczących bezpieczeństwa ruchu statków powietrznych i innych obiektów lotniczych w przypadkach przewidzianych przez przepisy dotyczące korzystania z przestrzeni powietrznej stron, oraz pomoc dla statków powietrznych w przypadku użycia wobec nich siły w locie. Siedziba kierowania systemu mieści się w Almacie (Shibutov, Solozobov, Malyarchuk, 2019, s. 41-42).

Oba kraje nawiązywały także współpracę w kwestii spraw dwustronnej działalności w przestrzeni kosmicznej, o czym przypomina dzierżawa przez Rosję kompleksu kosmicznego Bajkonur zlokalizowanego na terytorium Kazachstanu. Kompleksową umowę w przedmiotowej kwestii podpisano w marcu $1994 \mathrm{r}$. W niej znalazł się zapis o wynajmie obiektu do 2034 r. W 2004 r. na mocy porozumienia obu krajów wydłużono termin dzierżawy aż do 2050 r. Ponadto Rosja i Kazachstan zadeklarowały możliwość realizacji wspólnych projektów kosmicznych (Bałuk, 2008, s. 261). Obecnie na terenie wspomnianego kosmodromu powstaje system kazachskich rakiet kosmicznych „Baiterek”. Kompleks Bajkonur kierowany jest przez przewodniczących z obu krajów, I. I Shuvalova i K. N. Kelimbetova (zob. Russia-Kazakhstan). Chociaż niejednokrotnie pojawiały się informacje, że strona kazachska nie jest zainteresowana kontynuacją współpracy w obszarze dalszego wykorzystywania przez Rosjan obiektu jedynie do celów wojskowych, to jest jednak mało prawdopodobne, by Rosja miała zrezygnować z tego przedsięwzięcia. Niewątpliwie jednak władze w Nursułtanie będą dążyć do tego, żeby wykorzystać Bajkonur także do celów turystycznych. Potwierdza to minister Atamkulov, wskazując, że status cywilny kosmodromu pozwoli przyciągnąć większe zainteresowanie sektora prywatnego tą placówką eksploracji przestrzeni kosmicznej. Minister powiedział także, że zaangażowanie prywatnych firm może doprowadzić do lotów „tysięcy” satelitów z Bajkonuru (Kumenov, 2018). 


\section{STOSUNKI KAZACHSKO-ROSYJSKIE W WYMIARZE EKONOMICZNYM}

Niniejsze opracowanie dotyka również problematyki relacji obu interesujących nas podmiotów państwowych w wymiarze ekonomicznym. W uzupełnieniu ścisłych więzi gospodarczych Rosji z Kazachstanem prezydent Nazarbajew z początkiem lat 90. ubiegłego wieku zdecydował o ściągnięciu do kraju kapitału zagranicznego, co miało także skutkować możliwościami znalezienia nowych rynków zbytu. Przyczynkiem do tego miała być opracowana w 1994 r. strategia niezależności ekonomicznej Kazachstanu jako jednego z atrybutów suwerennego państwa (Nurgalyeva, 2016, s. 93). Do chwili obecnej jednak głównym partnerem gospodarczym jest Rosja. Najważniejszym obszarem współpracy pozostał sektor paliwowo-energetyczny. Oba państwa w szczególnej mierze dbają o rozwój kooperacji w sferach elektroenergetyki oraz energetyki jądrowej, powiązanych ze wspólną eksploatacją złóż kazachskiego uranu oraz synchronizacją działania systemów energetycznych. Istotną rolę we wzajemnych kontaktach odgrywa także przemysł naftowy i gazowy, a szczególnie eksport kazachskiej ropy przez terytorium Rosji. Nursułtan i Moskwa realizują ponadto wspólne projekty eksploracji zasobów węglowodorów z Morza Kaspijskiego (zob. Russia-Kazakhstan). Kontakty ekonomiczne nie były jednak wolne od napięć. Jednym z elementów spornych była kwestia statusu Morza Kaspijskiego. Władze w Astanie dążyły do uregulowania powyższej sprawy przez odwołanie się do Prawa Morza, lecz zdawały sobie sprawę, że takie stanowisko spotka się z dezaprobatą Moskwy. Dlatego w 1995 r. minister spraw zagranicznych Kazachstanu W. Gazzatow zasugerował kompromis polegający na dokonaniu delimitacji podziału dna i złóż Morza, szczególnie jego północnej części. Ostatecznie Moskwa i Astana podpisały w 1998 r. porozumienie w tej sprawie, uzgadniając, że rozgraniczenie będzie według linii środkowej, uwzględniającej położenie wysp i strukturę geologiczną dna (Bałuk, 2009, s. 200-202). Pomimo to Kreml zachował do chwili obecnej dominującą rolę, co jest widoczne w kontroli przez rosyjskie koncerny energetyczne większości zasobów Morza na etapie wydobycia i transportu (Piechowiak- Lamparska, 2017, s. 198).

Należy zwrócić uwagę, że intensyfikacja kontaktów gospodarczych między oboma państwami datuje się na początek rządów Władimira Putina. Jej przejawem było powstanie w 2001 r. Szanghajskiej Organizacji Współpracy, w której obok Rosji i Chin Kazachstan był jednym z członków założycieli. Niniejsza instytucja, podkreślająca w przyjętych założeniach budowę zaufania i stosun- 
ków dobrosąsiedzkich, kooperację w celu utrzymania pokoju, bezpieczeństwa i stabilności w regionie, przeciwdziałanie wszelkim działaniom terrorystycznym i separatystycznym, czy wreszcie ułatwienie wszechstronnego i zrównoważonego rozwoju gospodarczego, społecznego i kulturalnego swoich członków (Perkowska, 2010, s. 61-62), stanowi dla Moskwy i Pekinu narzędzie kontroli nad pozostałymi członkami organizacji, w tym nad Kazachstanem. Tymczasem w kwietniu 2004 r. Nazarbajew otwarcie stwierdził, że integracja ta musi być pragmatyczna, oparta przede wszystkim na efektywności ekonomicznej wzajemnych kontaktów gospodarczych. Ówczesny prezydent dodał, że przedmiotowa integracja powinna być wielopoziomowa i może mieć różne prędkości, zgodnie z rozwojem gospodarczym każdego kraju członkowskiego. Wreszcie, jego zdaniem, jej istotą powinna być dobrowolność przyczyniająca się do zapewnienia na obszarze postradzieckim zbiorowego bezpieczeństwa regionalnego (Nurgalyeva, 2016, s. 95). W założeniach byłej głowy kazachskiego państwa wyraźnie widać dążenia do stworzenia zrzeszenia, które byłoby z jednej strony przeciwwagą dla zachodnich organizacji polityczno-ekonomicznych, a z drugiej zapewniało bezpieczeństwo na obszarze postradzieckim. Nie bez racji Nazarbajew wyrażał daleko idącą wstrzemięźliwość co do bilateralnych układów z Kremlem, sądząc, że jedynie multilateralne porozumienia mogą stanowić daleko idącą szansę osłabienia z jednej strony rosyjskiej kontroli, zaś z drugiej strony dążeń Zachodu do dominacji na tym obszarze. Pomimo faktu, że Szanghajska Organizacja Współpracy (SOW) stanowi jednak w pewnym zakresie instrument kontroli Kremla nad Kazachstanem, to nie należy zapominać, że członkostwo Nursułtanu w Organizacji jest na rękę obecnym władzom. Nastawiona z nieufnością do Zachodu kazachska ekipa rządząca zdaje sobie sprawę z jego dążeń do uzyskania większych wpływów w Kazachstanie oraz sprzeciwia się narzucaniu ustroju demokratycznego, który może przyczynić się do odsunięcia stronników Nazarbajewa od władzy. Ponadto rządzące elity w Kazachstanie oraz innych krajach członkowskich SOW pragną utrzymać dobre relacje z Kremlem, gdyż to Rosja zapewnia im część zachodnich technologii, potrzebnych do rozwoju gospodarki oraz armii (Sikora-Gaca, 2015, s. 208).

Kolejnym ważnym instrumentem współpracy gospodarczej interesującego nas regionu jest działalność Euroazjatyckiej Unii Gospodarczej (EAEU), powołanej w Astanie w maju 2014 r. Organizacja ta, mająca w założeniu przyczyniać się do intensyfikowania więzi gospodarczych między krajami postsowieckimi, stała się dodatkowym elementem nacisku Kremla na państwa poradzieckie, jeśli zdecydowałyby się one na zmianę kursu polityki w stronę Zachodu. Członkami Unii 
są Armenia, Białoruś, Kazachstan, Kirgistan oraz Rosja, zaś do najważniejszych priorytetów działań tej organizacji należy zaliczyć: rozwój wzajemnego handlu i inwestycji oraz ujednolicenie i ograniczenie barier pozataryfowych (Walerjan, Kowalska, 2018, s. 4-5). Można wysnuć wniosek, że Rosja i Kazachstan stają się sobie z roku na rok coraz bliższe ekonomicznie, skupiając się w swoich działaniach nad uproszczeniem dwustronnego przepływu towarów, usług, ludzi i kapitału. Jednocześnie autor zaznacza, że rosyjskie inwestycje w Kazachstanie nie są specjalnie nagłaśniane w sferze publicznej z uwagi na ich charakter podporządkowujący sobie mniejszego kooperanta. Kazachstan pozostaje atrakcyjny dla Rosji z racji bezpośredniego sąsiedztwa, braku barier językowych oraz tożsamego ustroju politycznego i gospodarczego (zob. Russia and Kazakhstan: What's Next?, 2019).

Jednakże aneksja Krymu i nałożone przez Zachód sankcje na Rosję wymiernie wpłynęły na osłabienie relacji rosyjsko-kazachskich w sferze ekonomicznej. Znaczące obniżenie cen na światowych rynkach surowcowych, także negatywnie odbiło się na Rosji, a szczególnie na Kazachstanie, gdyż sektor naftowy tego kraju odpowiada za ok. 1/3 jego PKB (Morawska, 2018, s. 252). Potwierdza to Zaborsteva, według której kooperacja z państwami eksporterami ropy i kryzys ukraiński spowodowały pogorszenie się sytuacji gospodarczej w Kazachstanie (Zaborsteva, 2016, The Impact of the Ukrainian Conflict, s. 13). Warto zaznaczyć, że dla Kazachstanu Rosja jest głównym miejscem inwestycji wśród pozostałych krajów WNP - stanowi ich co najmniej 50\%, a w niektórych branżach osiąga nawet 90\%, osiągając jednocześnie jedynie 5\% w skali światowej (Shibutov, Solozobov, Malyarchuk, 2019, s. 27). Jednym z liderów wśród partnerów gospodarczych Kazachstanu jest Unia Europejska, aczkolwiek wymiana handlowa z nią stanowi tylko 0,5\% eksportu wspólnoty z państwami trzecimi (Morawska, 2018, s. 253). Głównym partnerem bilateralnym dla Kazachów pozostaje jednak Rosja, inwestująca w gospodarkę Kazachstanu średnio 12,6 miliardów dolarów. W pierwszej połowie 2018 r. Rosja zainwestowała dodatkowe 821 milionów dolarów, głównie w sektorze finansowym. Pomimo zawirowań liczba rosyjsko-kazachskich wspólnych przedsięwzięć stale rośnie. Aktualnie jest ich ponad 6000, co stanowi jedną trzecią wszystkich przedsięwzięć z udziałem zagranicznym. AvtoVAZ, EuroChem, Gazprom, KAMAZ, Lukoil, Mechel, Rosatom, Roscosmos, Rostec, Rostselmash, Rusal, Russian Copper Company, Vimpelcom (Beeline), Yandex i wiele innych dużych, średnich i małych rosyjskich przedsiębiorstw z powodzeniem funkcjonuje biznesowo na rynku kazachskim. Wzrasta współpraca w sektorach finansowym i bankowym za sprawą obecności w Kazachstanie 
poniższych podmiotów, jak: Alfabank, Gazprombank, Rosyjski Bank Rolny Sbierbank czy VTB Bank. Prawie 70\% rosyjsko-kazachskiego handlu zagranicznego i transakcji finansowych odbywa się w walutach krajowych (Borodavkin, 2018). Wzajemna interakcja na różnych poziomach jest jednak nierówna i odbywa się z różną intensywnością. Według wspomnianych wcześniej Shibutova, Solozobova oraz Malyarchuk, najlepsza współpraca obu podmiotów ma miejsce na szczeblu przywódców państwowych oraz zwykłych obywateli, którzy odczuwają wobec siebie wzajemną sympatię. Dobra kooperacja jest prowadzona na poziomie eksperckim i regionalnym, najsłabsza z kolei na szczeblu parlamentarnym i biznesowym, czego dowodem jest niska aktywność zrzeszeń skupiających przedsiębiorców i handlowców obu krajów, m.in. Krajowej Izby Przedsiębiorców (ze strony Kazachstanu) i Izby Handlu i Przemysłu Rosji (Shibutov, Solozobov, Malyarchuk, 2019, s.17). Wydaje się uzasadnione stwierdzenie, że taki stan rzeczy jest związany przede wszystkim z ograniczoną rolą parlamentu i rządu obu krajów, gdzie władzę sprawują na wzór autorytarny prezydenci, cieszący się znacznym poparciem społecznym i kontrolujący poprzez zaufanych ludzi wszelkie gałęzie biznesu oraz spółki, których przedstawiciele stosują się ściśle do dyrektyw władz, unikając przy tym przejawiania własnej inicjatywy. Biznesmeni zdają sobie sprawę, że to głównie wzajemna interakcja przywódców oraz wspólne interesy prowadzą do zacieśnienia wzajemnej współpracy, a nie „spontaniczne” kontakty działaczy ekonomicznych. Ponadto wypada stwierdzić, że między Kazachami a Rosjanami występuje jeszcze podskórne napięcie i nieufność, powodowane zaszłościami z okresu Związku Sowieckiego. Według D. Satpaeva nie ma długoterminowej strategii np. w sprawie przyszłego dwustronnego partnerstwa między Rosją a Kazachstanem, ponieważ nadal istnieją znaczne niedomówienia między nimi, a obecne relacje charakteryzuje w głównej mierze tylko wspólny interes (Nurgalyeva, 2016, s. 99).

\section{RELACJE KULTURALNE MOSKWA-NURSUŁTAN}

W przedmiotowej analizie nie należy również zapominać o kwestiach kulturowych. Chociaż od uzyskania niepodległości przez Kazachstan więzi tego rodzaju pomiędzy oboma państwami w zasadzie zostały utrzymane, to w ostatnich latach, szczególnie po aneksji Krymu, Nazarbajew odwoływał się do konieczności podkreślania kazachskiej państwowości i jej odrębności od tej rosyjskiej. Jednym z tego przejawów była podjęta przez byłego już szefa państwa decyzja odnośnie 
zmiany alfabetu w Kazachstanie z cyrylicy na łaciński. Projekt ten składa się $\mathrm{z}$ trzech etapów, $\mathrm{z}$ których pierwszy jest już w toku i przewiduje opracowanie reguł pisowni oraz uruchomienie aplikacji cyfrowych. Drugi etap, z terminem rozpoczęcia w 2021 r., obejmie tłumaczenie obowiązujących przepisów oraz ponowne wydanie paszportów, certyfikatów i licencji. Ostatni krok, planowany nie wcześniej niż w 2023 r., będzie polegał na wprowadzeniu zmian w organach administracji rządowej, lokalnych organach wykonawczych, państwowych mediach i organizacjach edukacyjnych (Gadimova, 2019). Inicjatywa szefa rządzącej partii wywołała w Moskwie, co zrozumiałe, zaniepokojenie, a nawet gniew. Według rosyjskiego publicysty, Michaiła Delagina, decyzja Nazarbajewa to „splunięcie Rosji w twarz”. Nieco łagodniej wypowiedział się politolog Stanisław Pritczin z Rosyjskiej Akademii Nauk, który wskazał, że jeśli decyzja ta ma aspekt ideologiczny, to jest to „negatywny krok”, który sugeruje osłabienie więzi z Rosją. Podobnie twierdzi Niezwismaja Gazeta, według której ograniczenie rosyjsko-kazachskiej „wspólnoty kulturowej” stanowi podważenie zasad, na których powstała Wspólnota Niepodległych Państw. Jej przerwanie ma być „poważnym sygnałem". Z kolei w Kazachstanie ustami kazachskiego politologa i publicysty Aidosa Saryma słusznie podkreślano, że chociaż Nazarbajew argumentował niniejszą decyzję czynnikami ekonomicznymi, to jednak dąży on do tego, żeby uniezależnić się od Rosji. Sarym podnosi tezę, że wpływ na takie posunięcia ma dorastające pokolenie Kazachów, niepamiętających czasów sowieckiej okupacji i bardziej sprzyjających dążeniom do suwerenności (Poczobut, 2017). Dodać należy, że oba kraje współpracowały w sferze historii i edukacji. Dowodem tego jest oświadczenie obu państw, w którym czytamy: „Kazachstan i Rosja nie akceptują żadnych prób fałszowania, przepisywania i „oczerniania” naszej wspólnej historii, która jest najważniejszą podstawą naszych sojuszniczych stosunków, przede wszystkim historii II wojny światowej”. Dokument ten podkreśla także odrębność tożsamości etnicznej, kulturowej, językowej i religijnej Rosji i Kazachstanu (Wiśniewski, 2019).

\section{ZAKOŃCZENIE}

Zatem jaką postać i intensywność będą miały w przyszłości relacje rosyjsko-kazachskie? W moim przekonaniu po rezygnacji Nazarbajewa z funkcji prezydenta Kazachstanu jego następca będzie kontynuował dotychczasową politykę wobec Kremla. Wykształcony w Związku Radzieckim Tokajew zdaje 
sobie sprawę, że nawet niewielka zmiana jej kursu wobec Federacji Rosyjskiej może zakłócić obecne w jego kraju stabilność i spokój. Aktualny prezydent jest również świadomy faktu, że dopóki jego poprzednik sprawuje funkcje szefa rządzącej partii oraz przewodniczącego Rady Bezpieczeństwa krajowego, to wdrożenie jakichkolwiek własnych koncepcji w polityce zagranicznej będzie utrudnione. Nie należy zapominać, że nadal istotną w kraju rolę odgrywa także rodzina Nazarbajewa, szczególnie córka, która została przewodniczącą Senatu, a więc formalnie drugą osobą w państwie, co może oznaczać potencjalną formę nacisku na Tokajewa, jeśli zdecydowałby się na zmianę priorytetów polityki zagranicznej kraju. Jednakże pierwsze gesty nowego prezydenta, chociażby wizyta w Moskwie, wskazują, że wzajemna kooperacja może ulec ożywieniu i intensyfikacji. Tokajew, który przez całą swoją karierę polityczną nie poznał w wystarczający sposób świata zachodniego, będzie więc z Moskwą współpracował, nie odwracając się jednocześnie od Zachodu. Można spodziewać się jednak pewnego rozluźnienia więzów prozachodniego stanowiska w związku z niezrozumieniem postradzieckiej rzeczywistości przez decydentów i społeczności tej formacji. Władze kazachskie zdają sobie sprawę, że zbyt szerokie otwarcie się na Zachód może skutkować ich osłabieniem od wewnątrz oraz określonymi protestami społecznymi, które z kolei mogą zdestabilizować system rządów, a także rozszerzyć się na inne postsowieckie kraje, co dla Kremla stanowiłoby już poważny problem. Można przypuszczać jednak, że jeśli relacje z Moskwą będą się stopniowo pogarszać, to aktualny prezydent, pełniący w przeszłości funkcje dyplomatyczne w krajach Dalekiego Wschodu, może zdecydować się na nieznaczną korektę polityki zagranicznej w stronę Pekinu, co nie wywoła zbyt daleko idących sprzeciwów, zarówno Nazarbajewa oraz jego popleczników, jak i Moskwy. Rosja mimo oficjalnie głoszonej propagandy o swojej mocarstwowości, coraz częściej jest przymuszana oddawać pole Pekinowi nie tylko na Dalekim Wschodzie, ale także na terytoriach dawnych azjatyckich postsowieckich republik. Moskwa nie posiada wystarczających instrumentów, żeby temu zapobiec. Jednocześnie prezydent Putin i jego najbliżsi współpracownicy uważają wzrost roli Pekinu w Kazachstanie za „mniejsze zło”, gdyż Chiny w gruncie rzeczy podzielają właściwości ustrojowe Kremla i także są nastawione antyzachodnio. Poza tym Moskwa nie bez racji uważa, że wzrost chińskich inwestycji w Kazachstanie może być jej na rękę w związku z przeżywanymi obecnie trudnościami ekonomicznymi po nałożeniu zachodnich sankcji za aneksję Krymu i zaangażowaniem się w wojnie we wschodniej Ukrainie. Wobec powyższego nie można wykluczyć, że Kreml, mimo wszystkich potencjalnych 
zagrożeń rozwoju spodziewanej kooperacji Nursułtanu z Pekinem, w rzeczywistości wyraża z tego tytułu określone zadowolenie. Dodać należy, że elita władzy Kazachstanu zmierza aktualnie do utrzymania poziomu wzajemnych relacji z Rosją, gdyż jej pomoc militarna oraz inwestycje gospodarcze Pekinu wspierają ten kraj w utrzymaniu określonej i znaczącej pozycji na arenie międzynarodowej (Wiśniewski, 2019). Kazachstan w polityce zagranicznej wyraźnie akcentuje współpracę z oboma sąsiadującymi z nim mocarstwami, co oznacza mało prawdopodobne otwarcie się na Zachód. Dlatego też nie należy spodziewać się istotnych zmian w stosunkach Rosja-Kazachstan.

\section{BiBLIOGRAFIA:}

Bałuk, W. (2008). Polityka bezpieczeństwa Republiki Kazachstanu. W: W. Bałuk, Z.J. Winnicki (red.). Wschodioznawstwo. Badania wschodnie. Polityka wewnętrzna i międzynarodowa (s. 251-267). Wrocław: Wydawnictwo Uniwersytetu Wrocławskiego.

Bałuk, W. (2009). Status prawny Morza Kaspijskiego i potencjalny podział zasobów naturalnych. W: Z. J. Winnicki, W. Bałuk, (red.). Wschodioznawstwo. Polityka wewnętrzna i międzynarodowa. Badania wschodnie (s. 195-214). Wrocław: Wydawnictwo Uniwersytetu Wrocławskiego.

Borodavkin, A. (2018). Russia and Kazakhstan: Past, Present, Future. Pobrane z: http:// $\mathrm{mfa}$.gov.kz/en/content-view/aleksej-borodavkin-resej-zne-kazakstan-tkenikazirgisi-bolasagy.

Budzisz, M. (2019). Kazachstan - czyli mała Rosja. Czy Putin pójdzie droga Nazarbajewa? Pobrane z: https://tygodnik.tvp.pl/41826160/kazachstan-czyli-mala-rosja-czy-putinpojdzie-droga-nazarbajewa.

Ducret, D., Hecht, E. (2014). Ostatnie dni dyktatorów. Kraków: Wydawnictwo Znak Horyzont.

Kazachstan upamiętnia stalinowski terror. Pobrane z: https://pl.globalvoices.org/2018/06/ kazachstan-upamietnia-stalinowski-terror/.

Gadimova, N. (2019). Kazakhstan's Government Refutes Russian Media Claim About Alphabet. Pobrane z: https://caspiannews.com/news-detail/kazakhstansgovernment-refutes-russian-media-claim-about-alphabet-2019-7-18-2/.

Hubner, W. (2014). Współczesny Szlak Jedwabny a tradycja: Chiny a Azja Centralna. Zeszyty Naukowe Uczelni Vistula, 34, 5-37.

Jarosiewicz, A. (2014). Kazachstan wobec integracji z Rosją: mniej miłości, więcej strachu. Pobrane z: https://www.osw.waw.pl/pl/publikacje/komentarze-osw/2014-05-26/ kazachstan-wobec-integracji-z-rosja-mniej-milosci-wiecej.

Jarosiewicz, A. (2016). Pierestrojka Nazarbajewa. Kryzys i reformy w Kazachstanie. Punkt widzenia, 6, 1-51.

Kacewicz, M. (2018). Kazachstan nie może się zerwać Rosji z uwięzi, ale potrafi poluzować smycz. Pobrane z: https://belsat.eu/pl/news/kazachstan-nie-moze-sie-zerwac-rosjiz-uwiezi-ale-potrafi-poluzowac-smycz/. 
Kassymova, D., Kundakbaeva Zh, B., Markus, U. (2012). Historical Dictionary of Kazakhstan. Lanham, Toronto, Plymouth: The Scarecrow Press.

Kazachstan: prezydent deklaruje działania na rzecz społeczeństwa obywatelskiego. Pobrane z: https://www.pap.pl/centrum-prasowe/478001\%2Ckazachstanprezydent-deklaruje-dzialania-na-rzecz-spoleczenstwa.

Korejba, J. (2012). Rosja bez Kazachstanu? Pobrane z: http://www.new.org.pl/1212-rosja-bez-kazachstanu.

Kośka, M. (2014). Kazachstan zwraca się ku Chinom. Pobrane z: https://www.obserwatorfinansowy.pl/tematyka/makroekonomia/kazachstan-zwraca-sie-ku-chinom/.

Kumenov, A. (2018). Kazakhstan: Russian military to leave Baikonur base? Pobrane z: https://eurasianet.org/kazakhstan-russian-military-to-leave-baikonur-base.

Legucka, A. (2013). Geopolityczne uwarunkowania konfliktów zbrojnych na obszarze postradzieckim. Warszawa: Wydawnictwo Difin.

Marszewski, M. (2019). Kazachstan - drugi etap kontrolowanej sukcesji. Pobrane z: https://www.osw.waw.pl/pl/publikacje/analizy/2019-06-12/kazachstan-drugi-etap-kontrolowanej-sukcesji.

Mazur, R. (2007). Wspólnota Niepodległych Państw. Integracja czy dezintegracja? Wschodoznawstwo, 1, 169-189.

Morawska, E (2018). Bezpieczeństwo Kazachstanu w dobie kryzysu. Rocznik Bezpieczeństwa Międzynarodowego, 1, 248-259.

Nazarbajew krytykuje Camerona: Nikt nie ma prawa nas pouczać. Pobrane z: https:// fakty.interia.pl/swiat/news-nazarbajew-krytykuje-camerona-nikt-nie-ma-prawanas-pouczac,nId,989387.

Nurgaliyeva, L. (2016). Kazakhstan's economic soft balancing policy vis-à-vis Russia: From the Eurasian Union to the economic cooperation with Turkey. Journal of Eurasian Studies, 7, 92-105.

Oka, N. (2006). Managing Ethnicity under Authoritarian Rule: Transborder Nationalisms in Post-Soviet Kazachstan. Pobrane z: http://www.ide.go.jp/library/Japanese/ Publish/Download/Report/pdf/2006_04_31_ch2.pdf, 34-71.

Perkowska, A. (2010). Szanghajska Organizacja Współpracy - geopolityka. Ekonomia i Zarzadzanie, 3, 58-74.

Relations with Russia crucial for Kazakhstan, president says. Pobrane z: https://tass.com/ world/1064072

Pichoja, R. (2011). Historia władzy w Związku Radzieckim 1945-1991. Warszawa: Wydawnictwo Naukowe PWN.

Piechowiak-Lamparska, J. (2017). International risk factors occuring in the Caspian Sea region. Athenaeum. Polskie Studia Politologiczne, 56, 193-204. DOI: 10.15804/ athena.2017.56.12.

Poczobut, A. (2017). Kazachstan porzuca cyrylice, a wraz z nią „rosyjski świat”. W jej miejsce wprowadza łaciński alfabet. Pobrane z: https://wyborcza.pl/7,75399,21634887,kazachstan-porzuca-cyrylice-a-wraz-z-nia-rosyjski-swiat.html.

Potocki, J. (2016). Kazachstan - potega w Azji Środkowej. Pobrane z: http://polska-zbrojna.pl/home/articleshow/20283?t=Kazachstan-potega-w-Azji-Srodkowej\#. 
Prezydent Kazachstanu oddaje tytuł, ale nie władzę. Co to oznacza? Pobrane z: https:// www.pch24.pl/prezydent-kazachstanu-oddaje-tytul--ale-nie-wladze--co-tooznacza---opinia-,66979, i.html.

Putin: Kazachowie nigdy nie mieli państwowości. Pobrane z: https://www.wprost.pl/ swiat/472439/Putin-Kazachowie-nigdy-nie-mieli-panstwowosci.html.

Rakowska E. (2005), Broń atomowa w Kazachstanie i Azji Środkowej. Pobrane z: http:// www.psz.pl/168-archiwum/ewa-rakowska-bron-atomowa-w-kazachstanie-i-azjisrodkowej.

Rosja: Tokajew do Putina: moim zadaniem jest kontynuacja relacji z Rosja (2019). Pobrane z: https://forsal.pl/artykuly/1406465,rosja-tokajew-do-putina-moimzadaniem-jest-kontynuacja-relacji-z-rosja.html.

Russia and Kazakhstan: What's Next? An Interview with Askar Nursha. Pobrane z: https://voicesoncentralasia.org/russia-and-kazakhstan-whats-next-an-interviewwith-askar-nursha/.

Russia-Kazakhstan, Pobrane z: http://www.rfembassy.kz/eng/lm/dvustoronnie_otnosheniya/rossiya-kazakhstan/

Shibutov, M., Y Solozobov, Y., Malyarchuk, N. (2019). Kazakhstan Russia Relations in Modern Era. Pobrane z: https://www.vision-gt.eu/wp-content/uploads/2019/01/ AD_Kazakhstan-Russia_1.pdf.

Sikora- Gaca, M. (2015). Szanghajska Organizacja Współpracy i jej wpływ na kształtowanie globalnego zarządzania. W: M. Rewizorski (red.). Instytucje międzynarodowe $w$ dobie globalnego zarzadzania (s. 196-215). Warszawa: Dom Wydawniczy Elipsa.

Tokarz, G. (2008). Uwarunkowania geopolityczne polityki zagranicznej Kazachstanu. W: W. Bałuk, Z.J. Winnicki. (red.). Badania wschodnie. Polityka wewnętrzna i międzynarodowa, (s. 239-250). Wrocław: Wydawnictwo Uniwersytetu Wrocławskiego.

Walerian Ł, Kowalska, O. (2018). Eurazjatycka Unia Gospodarcza - Ekonomia i możliwości współpracy. Pobrane z: https://kig.pl/wp-content/uploads/2018/07/2018_06_07-Raport-EUG.pdf.

Wiśniewski, S. (2019). Nursultan i Moskwa - strategiczni sojusznicy [ANALIZA]. Pobrane z: https://wschodnipunktwidzenia.wordpress.com/2019/04/11/nursultani-moskwa-strategiczni-sojusznicy-analiza/.

Van Noort, C. (2019). The Belt and Road Initiative and Kazakhstan: A Success Story? http://web.isanet.org/Web/Conferences/Toronto\%202019-s/Archive/ad4b7452ef97-4ef3-b2f1-be95f7712c13.pdf.

Zabortseva, Y. (2016). The Impact of the Ukrainian Conflict on Kazakhstan's FDI with Russia and its Other Main Economic Partners. Russian Analitycal Digest, 188, 11-14.

Zabortseva, Y. (2016). Russia relations with Kazakhstan, Rethinking Ex-Soviet Transitions in the Emerging World System. Routledge: Taylor \& Francis Group.

Załęski, P. (2006). Elity władzy politycznej Kazachstanu. Warszawa: Dom Wydawniczy Elipsa. 